\title{
A Relevance Theory Approach to the Scandinavian Influence upon the Development of the English Language
}

\author{
$\mathrm{M}^{\mathrm{a}}$ Angeles Ruiz Moneva \\ Universidad de Zaragoza
}

\begin{abstract}
The Scandinavians were one of the peoples whose stay in England was to affect the development of the English language in several and crucial ways. The impact of the Scandinavian language upon English, which may be studied from the perspective of the area of historical linguistics and language contact, was to be felt during the earliest stages of the development of the language, namely, the periods corresponding to Old and Middle English.

However, the influence of Scandinavian upon English was not of the same nature in either of the above mentioned periods of the language. On the whole, it is admitted that whereas during the Old English period the influence may be reduced in general terms to the extra linguistic factors, its effects were to be felt more directly upon the language during the Middle English period. To give just an example, this is the case of the double system of declensions for the personal and possessive pronouns that can be found in Middle English, according to the different parts or regions of England.

The aim of this paper will be to focus upon the areas in which the Scandinavian language influenced the subsequent development of the English language. Such impact was not only restricted to phonetics or semantics, but also influenced a field such as grammar. More concretely, those aspects in which the Scandinavian language has been most influential in the subsequent history of the English language will be analysed. The approach that will be followed is that of relevance theory, so as to show the ways in which the communicative balance between processing efforts and communicative effects may have caused certain phenomena under study.
\end{abstract}

One of the features which is commonly employed by scholars to establish the differences between the Old and the Middle English periods is the influence upon the language of the 
other peoples whom the Anglo-Saxons came in contact with. In this way, it is often stated that, whereas Old English tended to form new words on the basis of the composition of already existing terms, Middle English had often recourse to the borrowing of new words. On the whole, it seems that the most important source languages in these periods must have been Celtic, Latin, French and Scandinavian. The influences of these languages upon the development of English are acknowledgedly different. The Celtic influence is practically limited to certain place names, which is striking, on account of the fact that these languages were once one of the most extensive in the European family. The Latin influence is characterised by its status as a cultural lingua franca, which allowed English to introduce new concepts, as well as the adoption of many words. The impact of French upon English was also very great and was to be felt during the Middle English period onwards.

What distinguishes the Scandinavian influence upon the English language has been admitted to be the fact that the Scandinavian loans usually refer to ordinary events, things and circumstances (Fernández, F. 44). The Viking influence on England, as far as politics is concerned, covers from the middle of the eighth century to the beginning of the eleventh. However, it seems that the internal linguistic influences were to affect the language slower and later in time, although they were to become very important. It is often stated that whereas the Old English period provides the overall context for the influence to take place, this was to become manifest in the following period. As Dieter Kastovsky puts it, The Old English period is responsible for the extralinguistic situation that made borrowing on such a large scale possible, but the results of the process only became visible in Middle English (321).

The reason for this seems to be fairly general, in the sense that it tends to occur in the process of a certain contact between languages. The results of these contacts tend to take some time to be felt in the code, and be known, recognised and used, not just occasionally, but to become incorporated into the langue.

But historical factors are also relevant in this aspect, because in the case of the Scandinavian settlement in England, it was a gradual process, which covers from the initial, spontaneous and sudden raids to the extensive settlement and the peaceful amalgamation with the Anglo-Saxons. The result of this extensive process was the immigration and staying of an important number of Scandinavians in England. The Scandinavians were most likely to be found in those areas surrounding the Danelaw. A certain degree of mutual influence between the two peoples was possible on account of the fact that, as historians have shown, both lived long periods of peaceful settlement and life together, probably fostered by the great linguistic and cultural similarities between both peoples and the natural adaptability of the Scandinavians.

In the annal corresponding to the year 787, The Anglo-Saxon Chronicle refers to the arrival in England of the first ships of the Danes. The extent of their influence is to last during several centuries. Thus, contrarily to what had happened with the Celts, the Scandinavian influence upon the English language is characterised by its intensity, the great and important areas of the language which were affected, and the unfolding and development in time of the influence.

What is most characteristic and also most striking about the Scandinavian influence is the fact that the words borrowed by the English language are not superfluous terms, but form part 
of the common core of the everyday usage lexicon. Thus, among the borrowings, words which designate fundamental concepts can be found, and even, the borrowing of some grammatical forms, which is fairly uncommon in processes of language contact.

This also contrasts deeply with what will happen with the influence of French upon English following the Norman Conquest: then, the majority of words will refer to the aristocratic society, and will have to do with social institutions such as the government, politics, the nobility, commerce, art, culture and learning. On the contrary, the Scandinavian loans are much more "democratic" in tone and in character. This can be due to the fact that both the Anglo-Saxons and the Scandinavians are two very similar peoples. As Baugh, A.\& T. Cable put it,

The amalgamation of the two peoples was greatly facilitated by the close kinship that existed between them. The problem of the English was not the assimilation of an alien people representing an alien culture and speaking a wholly foreign tongue. The policy of the English kings in the period when they were reestablishing their control over the Danelaw was to accept as an established fact the mixed population of the district (94).

Such a close relationship between the two peoples and the fact that they spoke tongues which at least draw back to a common remote language ancestor, Germanic, may lead to think of a close relationship between the two languages. However, this can only remain as an assumption, because the written records in the Scandinavian tongue are rather scarce. Only a few specific cases provide us with reliable tests to determine the Scandinavian filiation of a word: the hard / sk/ sound, against the palatalised $/ \int /$, the hard pronunciation of $/ \mathrm{k} /$ and /g/, etc. Many of these changes will become more evident in the Middle English period. What seems clear is that many of the Scandinavian loans have been incorporated into the language, which cannot do without them. To give just a few examples, we may mention words such as sky, skin, shirt, skirt, get, give, etc. As can be deduced from the pair shirt-skirt, both the hard and the palatalized sounds may be maintained, but then they give way to different words. Examples such as these testify once more the main feature of the Scandinavian loanwords: their everyday usage, and the fact that even nowadays they are thought of as definite parts of the language.

The reasons that account for the slow but consistent influence of the Scandinavian language upon English are the following. Firstly, the fact that linguistic changes take time to develop; secondly, it must also be borne in mind that there is usually a difference between the oral and the written language, in the sense that the oral language is more unstable and more subject to changes. Before the situation in the linguistic contact between Anglo - Saxon and Scandinavian is analysed here, the contrast between oral and written language will be approached from the point of view of relevance theory (Sperber \& Wilson 1986). Very briefly, this theory may be based upon the following assumptions: contrarily to what has been traditionally thought, communication cannot be successfully accounted for on the exclusive basis of the code model, for which communication takes place when the addressee decodes or successfully understands the message sent or encoded by the addresser. For the inferential theories of communication, however, this does not give a sufficient explanation of the phenomenon, because it pays no attention to what the participants in the communicative act 
may infer from what is explicitly stated. The inferences made by the communicators are related to the context or cognitive environment of the communicative act and the shared knowledge between the speaker and the hearer.

All this leads to the basic maxim of this theoretical model: for communication to be optimally relevant, the processing costs of the information should be minimised, with a view to achieving the maximum possible communicative effects for the communicators in a certain context. The theory also assumes that whenever there is an increase in the processing effort, it is ultimately caused by an intended highlightening of the communicative effect.

These assumptions may be can be applied to the linguistic situation between the AngloSaxons and the Scandinavians in the sense that the oral language tends to reflect the linguistic changes because it is produced in a much more spontaneous way, and this causes the minimisation of the processing efforts. It may be said that in the oral form, the inferential axis of communication predominates over the code axis. On the contrary, when it comes to writing, the processing efforts are usually increased, because the expression tends to be more accurate.

Now, in the Scandinavian - Old English contact situation, the factor of the quantitative and qualitative existence of written records must also be taken into account, because, together with those influences that persist until the present day, it is the only record that we have to approach it. The problem is that the records kept are rather scarce, and this is a further reason why we have to wait for the situation in the Middle English period, where the Scandinavian influence appears much more explicitly. However, we do have other sources which should not be neglected and deserve further consideration, and which affect mainly the proper nouns, both anthroponimic and toponimic. In this sense, we might rather say that it is not a problem of scarcity of records in the Old English period, but that these records concern a somehow restricted, though by no means less important, area of the language.

All these factors may help to explain why the Scandinavian loans which cover wider semantic fields in the language start to appear in important proportions from the Middle texts onwards. From the relevance - theoretical point of view, these terms are most likely to be currently used when the processing effort required to understand them is reduced to the minimum possible. Otherwise, they would not be likely to be used thoroughly, because probably they would not have been sufficiently internalized by the speakers.

Another striking feature about the Scandinavian loanwords is the influence they have exerted upon the grammatical forms. Their similarity must have helped the mutual understanding between these two peoples, although it is difficult to state the degree up to which this may have been possible, and may have fostered the adoption of many content words. If we assume a certain degree of mutual comprehension, as Jespersen does, then we may conclude with him that "the intelligibility of either tongue [may have been] coming to depend mainly on its mere vocabulary" (75).

The fact that some words only differed in their inflectional endings seems to have contributed to the faster levelling of endings in the English language spoken in those areas with a higher degree of contact with the Scandinavians.

The adoption of Scandinavian loanwords is also fostered, as it often happens in language contact situations, by a question of prestige, especially when, as Kastovsky points out, (326) 
the Scandinavians came to occupy some official posts at Court. It is precisely this author that holds the view that the impact of the Danelaw and the Scandinavians upon the history of the English language implies to refer to a languages-in-contact situation. According to this author, the types of borrowings encountered may lead linguists to assume "either a fair amount of mutual intelligibility or relatively widespread bilingualism, and a considerable period of coexistence of the two languages involved" (327-8). The problem is that these factors cannot be established with a total security or certainty, and moreover, scholars do not really agree to characterise the situation as one of bilingualism.

In relevance-theory terms, so as to consider a language contact situation an instance of bilingualism, it can be assumed that communicative interchanges must have implied a practically inexistent effort in terms of decodification, or rather, the communicative effort required by the addressee to decodify the speaker's meaning should have been equivalent to the processing effort needed to decodify a message delivered in the native language, being the effect sought equivalent or similar in both cases.

In this way, we think that the classical hypothesis of mutual intelligibility can be overcome, because a practical shortcoming that this theory seems to have is that it is an exclusively linguistically based factor, which would imply the formal foundation of the theory, but not its functional adequacy. In the case of the explanation of bilingualism, it turns out that the mutual intelligibility hypothesis would establish that mutual intelligible paroles would correspond to the same langue, and therefore, they would have to be two different dialects or varieties of the same language (Robins, 1964). However, this hypothesis, which is linguistically or code-founded, cannot account for the possible fact that mutually distant dialects of the same language may become unintelligible, whereas geographically close and well socially connected, but still different, languages may be mutually understandable.

In the case of the mutual intelligibility between Anglo-Saxons and Scandinavians, there is no agreement among the different scholars who have dealt with this issue, (Kastovsky 328). Neither is it clear who may have become bilingual, either the Danes or the English or both. But the amount and quality of Scandinavian loans appearing in English shows that a certain degree of bilingualism must have existed, and that the transference of words from Scandinavian into English may have been favoured by Scandinavians adopting English. On the other hand, being English the submitted or conquered people, they may have found themselves somehow compelled to learn the language. Another factor is commercial interchanges, which would have shown the convenience of learning the foreign language. Intermarriage would also have favoured the contact between these two languages.

From the relevance-theoretical point of view, it appears that the flow of borrowed terms by the English language must have been based upon an internalized knowledge of this Scandinavian vocabulary, which would have come to be used when it accounted for the least possible processing effort for the speakers. Moreover, this is not the only reason, but the relative prestige acquired by the Scandinavian language, as well as the colloquial situations created by the lower society groups may have fostered the borrowing of a certain amount of words, whose acknowledgedly everyday character is the result of the similar cultural background of both the Scandinavian and the English peoples. 
We have already mentioned the striking number and types of everyday words that can trace back towards a Scandinavian origin. Let us mention just a few examples, given by Björn Wallner in his paper "The Distribution and Frequency of Scandinavian and Native Synonyms in King Alisaunder and Arthour and Merlin" (1959). The examples given, which will be referred below, widely corroborate Jespersen's description or hypothesis on the influence between Scandinavian and English words (1938). Many words must have been identical in both languages. When different words were used to refer to a definite entity, diffrerent things may have happened, but it is not uncommon that it is the Scandinavian loan that has come down to us ; or else, if both forms have been kept, it is the Scandinavian form that is more thoroughly used in Standard English. For instance,

$$
\begin{aligned}
& \text { OE }-.->\text { ey/Scand }--->\text { egg } \\
& \text { OE }-.->\text { yift/Scand }-->>\text { gift }
\end{aligned}
$$

The case may also be that both the native and the Scandinavian forms have survived, but with different meanings. A typical instance of this is constituted by pairs such as shirt vs. skirt.

Sometimes, the differences between the two forms are phonetically grounded, such as in

$$
\begin{aligned}
& \text { OE ---> benk } \\
& \text { Scand --->bench }
\end{aligned}
$$

In the same way, sometimes a word existing in both languages has maintained the Scandinavian meaning. For example, dream, which in Old English would have referred to something such as joy.

In some other cases, both forms have been maintained, but there is a difference in usage based upon diatopical variation: thus, pairs such as kirke/chirche are related to the Northern versus the Southern dialects in Middle English. However, it is interesting to note that some of these differences are still maintained in the Modern English period, and they can also be accounted for in terms of diatopic variation. Some of these forms may still be found in the Northern dialects, as Professor Fernández remarks (620). Some of them have a phonological basis to account for the use of Scandinavian forms: use of plosive versus the affricate phoneme, in pairs such as kist/chest, skift / shift ..., etc. These were important differences already in the Middle English period.

We shall try next to account for the relationship between Scandinavian and English in terms of a language contact situation. An important number of the assumptions we take are based upon the theories of Kastovsky and Burnley. Indeed, it is striking to find how some authors went so far as to claim that the language spoken in England and in Denmark was the same. In this seense, we think that a more moderate position can be held, related to the existence of a Germanic filiation in both languages. Moreover, some factors which may have favoured a certain degree, although its precise extent cannot be established, of understanding would have been the shared grammatical forms between both languages, and the lexical terms which were borrowed by English. With regard to this, David Burnley points out that 
Where the two languages were in close contact, something akin to pidginisation may have taken place quite quickly (...). The sociolinguistic situation is exceedingly complex, but over a long period both this transient pidgin and the Scandinavian language itself died out.

(Hansen 1984), giving way to English, and bequeathing it to a rich legacy of lexical loans as it did so (418).

We may attempt to set a tentative hypothesis, so as to try to account for the linguistic contact between Scandinavian and Old English in terms of pidginisation and creolisation in the following way: Out of the close contact between the two languages an "artificial" language may have been developed, which would be a sort of interlanguage. This language would have been used as a lingua-franca in order to facilitate the mutual understanding and communication for practical purposes. If we assume, as Burnley does, that both the temporary pidgin and the Scandinavian language itself gradually disappeared with the course of time, it turns out that the creole resulting out of the linguistic contact situation would be the English language, enriched with the great number of Scandinavian loanwords adopted, which were both lexical as well as grammatical.

It seems that the natural delay for the appearance of the loanwords responds to a series of reasons: the lack of written records of this period; the fact that, as we tried to show above, although the loans may have become to a certain extent easily incorporated into the oral language, it takes them longer to appear in the written form, and this factor is further reinforced by the peculiar situation which the Scandinavian language faced in England: at this stage, the only cultural sources were mainly oral and local, and also there are practically scarce, at least in diversity, written records, mainly because Scandinavian or Old Norse was not a literary language yet, and, as we tried to point out above, the appearance of the loans in a written form takes some time, if only because they need to be assimilated. As Burnley points out,

Scandinavian words filtered slowly into the written language only after the Conquest, when training in the Anglo Saxon standard was terminated and scribes began once more to write on a broader range of topics in the forms of their own local dialects (419).

In this sense, the adoption of Scandinavian terms may be somehow paralleled with something fairly similar that will occur with the linguistic contact between French and English: the situation of linguistic contact and bilingualism was also very complex at the time, depending to a greater extent on the social groups involved in the linguistic contact, but it seems that the major number of incorporations of French loanwords into the English language took place precisely when the use of English in Britain was on the decline. This would show that people who had been just previously accustomed to speaking in French were shifting towards a general and usual employ of English, which would foster, however, the incorporation of the loans because the corresponding genuinely Anglo-Saxon terms must have become out of use at the time, and may even have become old fashioned or unknown. In a parallel way, the incorporation of Scandinavian terms may have meant that they were becoming to be known and used. However, the Scandinavian-English contact situation is differentiated from the former in that here the contact remained in the scope of practical and immediate requirements. Although, as Burnley points out, (420), this would not have 
involved "to master the full resources of the language", it might have fostered the transference of common, everyday words, in which, as he explains, "a certain degree of substitution of the forms of the borrower's language into the patterns adopted" may have taken place.

Again, the main purpose must have been to make communication fluent and relevant to the speaker's and the listener's situation ; that is, speakers must have attempted to communicate with the highest possible efficiency, but yet involving the least possible communicative efforts. This may be one of the reasons to account for the fact that the substitution tended to be phonological, and also that different doublets may have existed to refer to the same concepts. In a general sense, the preferred form must have been the one with which maximum mutual understanding was achieved. The objective to lead towards the maximum possible understanding with the least possible effort would also probably lie behind the grammatical simplification, which was earlier developed, as scholars have shown, in those areas of heavier linguistic contact. The aim here would have been to get the most important referential ideas, for which the inflectional endings must have been fairly superfluous. The faster elimination of these endings would also have been favoured by the oral character of the interchanges, in the sense that for this kind of context the effort conveyed in communication, which aims at referential content rather than at linguistic or formal accuracy, would be relevant. It seems to be a fact that languages tend to evolve more rapidly in an oral form. Thus, following Weinrich (11) it might be said that these phenomena, after having occcurred in an oral form, they would "have become habitualized and established".

\section{Works Cited}

Algeo, J. Problems in the Origins and Development of the English Language. New York: Harcourt Brace Jovanovich, 1982.

Baugh, Albert C. \& Thomas Cable. A History of the English Language. London: Routledge \& Kegan Paul, 1951.

Bloomfield, M. \& L. Newmark. A Companionto Old and Middle English Studies. Greenword Press, 1979.

Brook, G.L. An Introduction to Old English. Manchester: Manchester University Press, 1978.

Burnley, David. "Lexis and Semantics ". In BLAKE, Norman. (ed.) The Cambridge History of the English Language. Vol. II. Cambridge: C.U.P., 1922, 409-451.

Clark, Cecily. "Onomastics". In HOGG, Richard. (ed.) The Cambridge History of the English Language. Vol. I. From the Beginnings to 1066. Cambridge: C.U.P., 1922, 542-608.

De La Cruz, Juan. La prosa de los anglosajones. Universidades de Málaga y Salamanca, 1983.

Fernández, Francisco. Historia de la lengua inglesa. Madrid: Gredos, 1982.

Fisiak, Jacek. A Short Grammar of Middle English. Oxford: O.U.P, 1968.

Givon, Talmy. (1979). "From Discourse to Syntax: Grammar as Processing Strategy". In Syntax and Semantics, XII (1979): 81-112.

Gutt, Ernst August. Translation and Relevance. Cognition and Context. Oxford: Blackwell, 1991. Hatim, Basil \& Ian Mason. Discourse and the Translator. London: Longman, 1990.

Jespersen, Otto. Growth and Structure of the English Language. London: Blackwell, 1938. 
Kastovsky, Dieter. "Semantics and vocabulary". In HOGG, Richard (ed.) The Cambridge History of the English Language. Vol. I . From the Beginnings to 1066. Cambridge: C.U.P., 1992, 320-336.

Kelly, L.G. Description and Measurement of Bilingualism. Toronto: Toronto University Press, 1969.

Kniezsa, Veronika. "The Scandinavian elements in The Peterborough Chronicle". In Fernández, F., M. Fuster, \& J,J. Calvo. Current Issues in Linguistic Theory. English Historical Linguistics. Amsterdam: John Benjamins Publishing Co., 1994, 235-245.

Leith, D. A Social History of English. London: Routledge \& Kegan Paul, 1983.

Mitchell, B. \& F. Robinson. A Guide to Old English. London: Blackwell, 1986.

Mosse, F. A Handbook of Middle English. Baltimore: John Hopkins Press, 1986.

Odenstedt, Bengt. "Who was Wulfstan". In HERMODSSON, Lars. (ed.) Studia Neophilologica. A Journal of Germanic and Romance Languages and Literature, 1994, 147-157.

Partridge, A.C. A Companion to Old and Middle English Studies. London: André Deutsch, 1982.

Pyles, T. \& J. Algeo. The Origins and Development of the English Language. New York: Harcourt Brace Jovanovich, 1982.

Rayfield, J.R. The Languages of a Bilingual Community. The Hague, 1970.

Reaney, P.H. The Origin of English Surnames. London: Routledge \& Kegan Paul, 1967.

Robins, R.H. General Linguistics. An Introductory Survey. London: Longman, 1964.

Robins, R.H. A Short History of Linguistics. London: Longman, 1967.

Sperber, Dan \& Deirdre Wilson. Relevance. Communication and Cognition. London: Blackwell, 1986.

Strang, Barbara. A History of English. London: Methuen, 1970.

Sweet, Henry. The Student's Dictionary of Anglo-Saxon. Oxford: Clarendon Press, 1976.

Wallner, Björn. "The Distribution and Frequency of Scandinavian and Native Synonyms in Kying Alisaunder and Arthour and Merlin". In English Studies, XL, (1959), 337-352.

Weinrich, U. Languages in Contact. Findings and Problems. The Hague: Mouton, 1953.

Wright, J \& E.Weight. An Elementary Middle English Grammar. Oxford: OUP, 1979. 